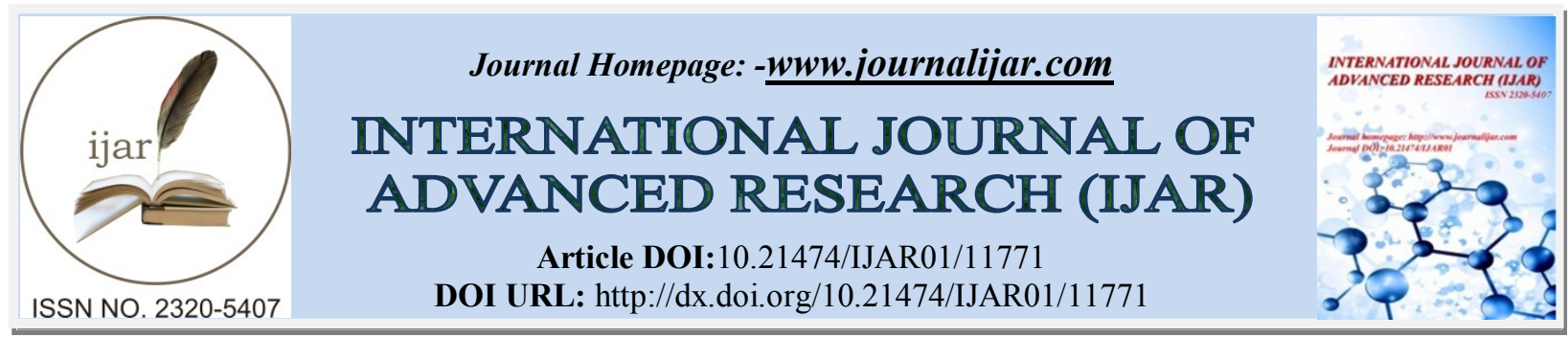

RESEARCH ARTICLE

\title{
ANALYSIS OF SHORELINE CHANGE IN COASTAL AREA OF SUBANG WEST JAVA INDONESIA FROM 2010 TO 2019 THROUGH SATELLITE IMAGERY
}

\author{
O. Pattipawaej and G. Hardiyan
}

Departement of Civil Engineering, Universitas Kristen Maranatha, Bandung, Indonesia.

\section{Manuscript Info}

Manuscript History

Received: 20 July 2020

Published: September 2020

Key words:-

Abrasion, Accretion, Satellite Imagery, Shoreline Change
Final Accepted: 24 August 2020

\begin{abstract}
The condition of beaches in Indonesia is currently quite concerning. Indonesia's mangroves and coastal sand are in danger of being damaged. Commitment from all parties is needed to overcome coastal damage. If not, the negative impact will be dangerous for the existence of coastal communities. Damage to coastal is a serious threat to the surrounding ecosystem, even tends to harm humans. Not only waste carried by the flow into the sea, but also garbage disposed of around the coastal areas of the sea and poor land management are clearly some actions that can reduce the carrying capacity of the environment. This carriage a serious threat to the environment. The beach in Subang district, West Java has quite severe coastal damage. Analysis of shoreline changes is needed to overcome the damage to the coast. The method used to analyze shoreline changes is through satellite mapping using Google Earth. The results obtained from 10 years of coastline satellite mapping in Subang Regency are changes in coastline and area that occur due to erosion and/or accretion. These results will help to challenge erosion and/or accretion. The next step can be made a coastal protection in the form of mangrove plants or coastal protection structures.
\end{abstract}

Copy Right, IJAR, 2020,. All rights reserved.

\section{Introduction:-}

The conditions around the coastal areas in Indonesia are one of the natural phenomena that have an important role and are closely related to nature and human activities. Natural processes, such as wind, waves, earthquakes and tsunamis occur in Indonesia. This natural process can cause damage to coastal areas, such as rising sea levels due to an increase in the volume of sea water which is seen periodically or continuously seen from the phenomenon of tides. The continuous sea level rise identified by global warming can cause the reduction or retreat of the coastline, accelerating theoccurrence of coastal erosion, flooding in coastal areas, and damage toinfrastructure in coastal areas such as piers and other coastal structures [1].The second phenomenonis human activity itself which causes coastal erosion, such as clearing new land bycutting down mangrove forests for the benefit of settlements and infrastructure development [2]. One of the mangrove forests around the coast is a natural protection for the coast. This natural phenomenon and human activities indicate that changes in the coastline have a very significant impact on life and ecosystems and other conditions on the coast [3].

Coast is a geographical form consisting of sandand is found in coastal areas of the sea. The coastal area is the boundary between land and sea waters. The coast occurs because of the waves that hit the edge of the land without 
stopping.The length of this coastline is measured around the entire coast. According to [4], the coastline is the boundary of sea and land water which is always changing very dynamically and interacting with each other, temporary changes such as tides and changes in abrasion with accretion over a long period of time so that the zone produces a unique environment and is vulnerable to change. Certain shoreline changes will occur because the coast is dynamic $[5,6,7]$. One of the consequences of shoreline changes is erosion which causes damage to beach and disrupts activities around the coast. On the other hand, the sea line can change due to abrasion, namely the erosion of the coast by the impact of sea waves which causes a reduction in the land area [8].

The investigated of coastline is in coastal area of Subang Regency, West Java, which borders the Java Sea to the north. The Subang coastline is $48.20 \mathrm{~km}$ and has an area of 13,380.27 ha. Therefore, economic activity in the region is centered on fisheries and trade and has environmental impacts and pressures on its surroundings [9].Based on the phenomenon that occurs, it is necessary to analyze changes in the coastline in the Subang Regency, West Java (Fig. 1). Satellite mapping from Google Earth[10,11] and using AutoCAD[12] as a support tool for this research.

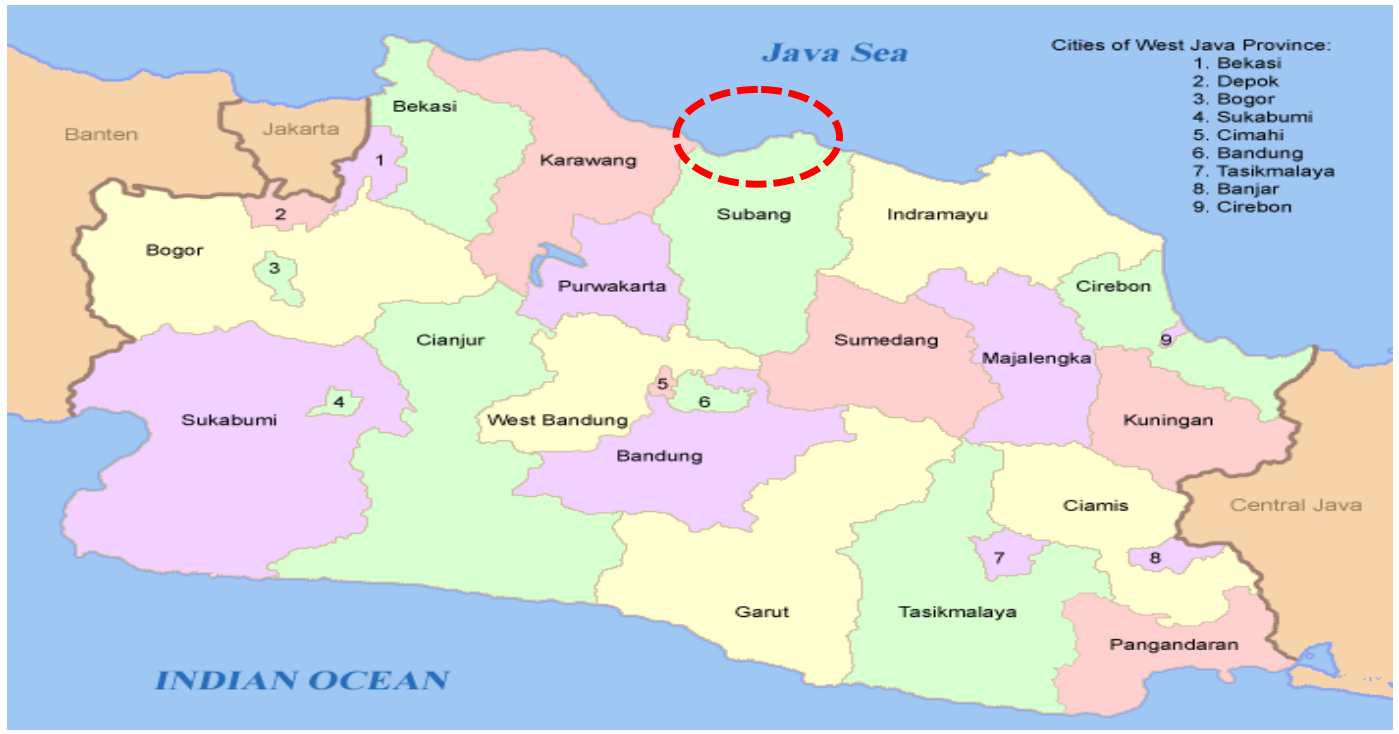

Fig. 1:- Subang Coastal Area.

\section{Methodology:-}

Several beaches in the territory of Indonesia have undergone many shorelines changes due to abrasion and accretion. Currently, the coast in the coastal area of Subang Regency is used in various land use activities to support local community income.Several factors that exist in the coastal area of Subang Regency, West Java can cause warning sign of changes in coastlines [9]. Changes that occur in the coastline can be monitored using a technology. Where the technology used in monitoring shoreline changes is using satellite imagery.Remote sensing is the science that is done by a person or group in examining objects or objects to obtain the desired information $[13,14,15,16,17,18]$. For the purposes of planning and management of coastal areas in Subang Regency, West Java, research is needed on the study of shoreline changes using a remote sensing approach in the coastal areas of Subang Regency.

This study aims to determine and map changes in coastline in the coastal area of Subang Regency by using satellite imagery comparisons. The results of this study are expected to provide information to the government, the community and various parties about changes in the coastline that occur along the coast of the coastal area of Subang Regency and can be used as a reference in the development and management of coastal areas.In this study, data coastline from 2009 to 2019 were used which were obtained from mapping satellite images sourced from the software/via the Google Earth Pro application (Fig. 2). 


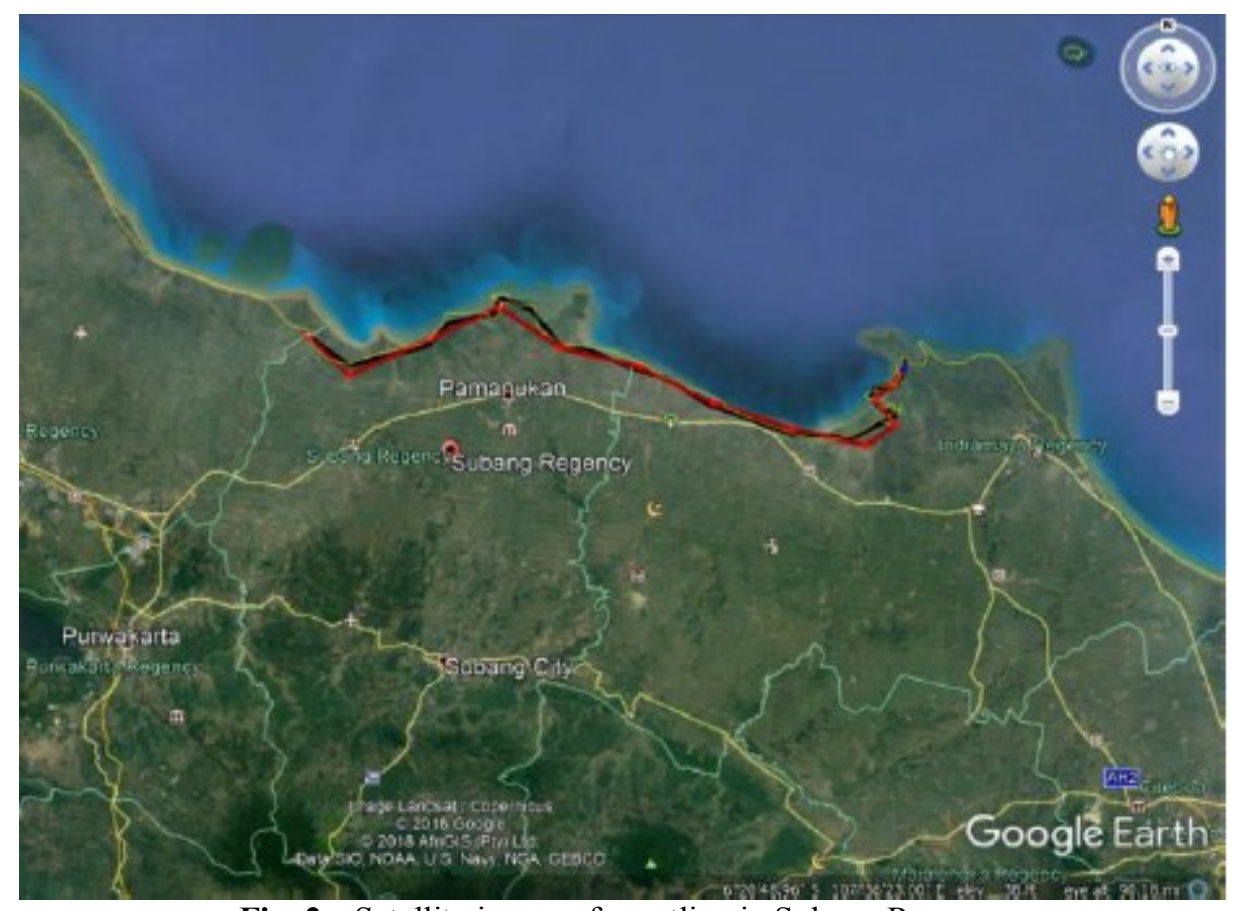

Fig. 2:- Satellite image of coastline in Subang Regency.

Shoreline change modeling to determine the characteristics of changes in each line in each year by modeling the distance between the changes. The modeling is divided into 2 parts, namely the distance in every $10 \mathrm{~km}$ (Fig. 3) and in every $3 \mathrm{~km}$ (Fig. 4) from the starting point coordinates to the end point coordinates.

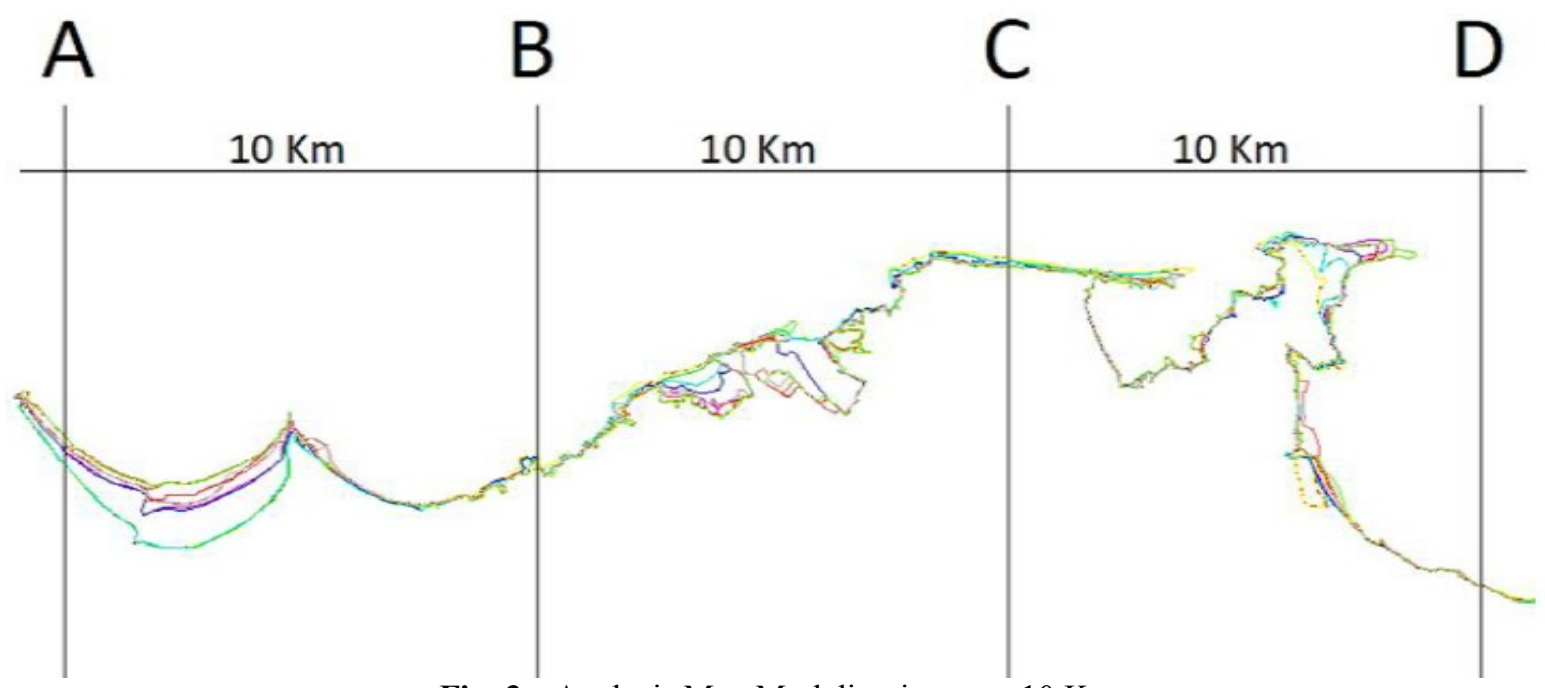

Fig. 3:- Analysis Map Modeling in every $10 \mathrm{Km}$. 


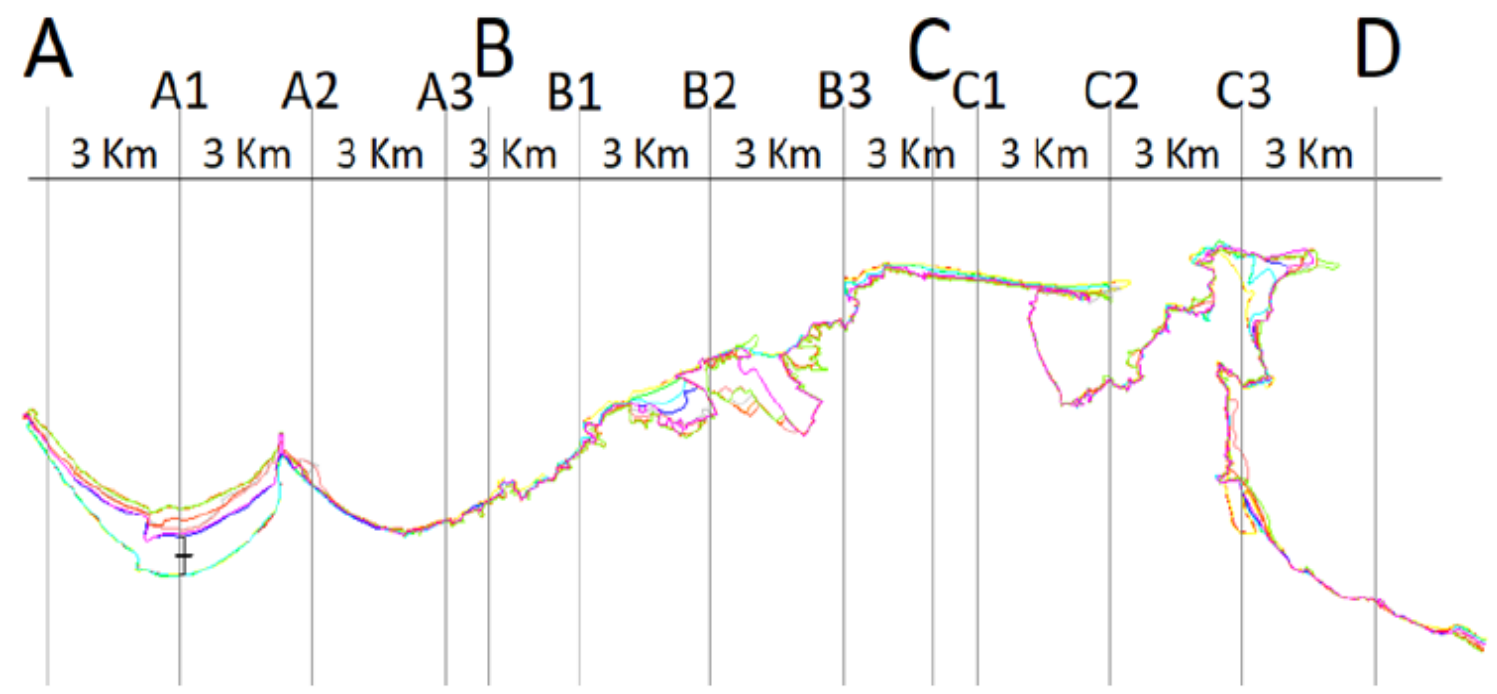

Fig. 4:- Analysis Map Modeling in every3 Km.

Shoreline changes in route analysis is to make route boxes with a size of $1000 \mathrm{~m} \times 1000 \mathrm{~m}$. The route boxes are connected in an orderly manner to cover all coastlines to be studied. The process of determining the area to be calculated is by means of a visual way where it can be seen areas with very extreme potential for abrasion/accretion, based on shoreline data. The data of the coastline has been previously formed by digitizing using Google Earth and has been converted into AutoCAD. By making polygon/line to calculate distance and area of shoreline change in a period using the properties feature in the AutoCAD.Figure 5 shows the route analysis map modeling.

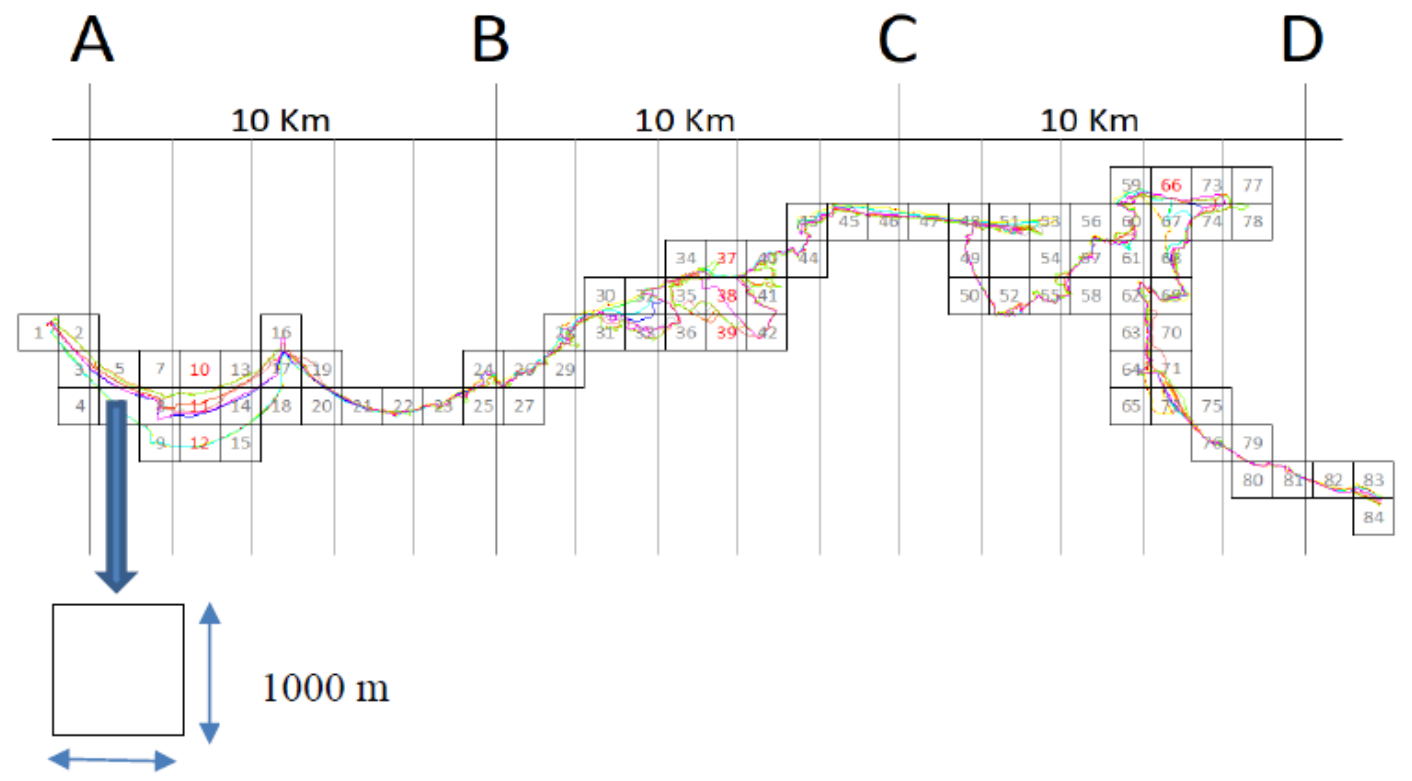

$1000 \mathrm{~m}$

Fig. 5:- Modeling Route Analysis.

\section{Results and Discussions:-}

The first modeling with a distance in every $10 \mathrm{~km}$ from the starting point of the coordinates to the end point of the coordinates from the mapping results of Google Earth in the year 2009 to the year 2019. In modeling from the digitization results of Google Earth satellite imagery converted toAutoCAD, it can be obtained the distance in every location point studied in accordance with the year shown in Table 1. 
Table 1:- Changes in coastline from 2009 to 2019 in every $10 \mathrm{~km}$.

\begin{tabular}{|c|r|r|r|r|}
\hline Year & $\mathrm{A}(\mathrm{m})$ & $\mathrm{B}(\mathrm{m})$ & $\mathrm{C}(\mathrm{m})$ & \multicolumn{1}{c|}{$\mathrm{D}(\mathrm{m})$} \\
\hline $2009-2010$ & $-3,66$ & $+39,83$ & $+1,24$ & $+1,79$ \\
\hline $2010-2011$ & +0.56 & $-154,78$ & $+1,12$ & $+1,12$ \\
\hline $2011-2012$ & $-1,60$ & $-2,85$ & $+1,69$ & $+1,69$ \\
\hline $2012-2013$ & $+278,67$ & $+11,14$ & $+4,49$ & $+4,49$ \\
\hline $2013-2014$ & $+32,32$ & 0 & $-2,02$ & $-2,02$ \\
\hline $2014-2015$ & $+153,70$ & $-111,47$ & $+2,43$ & $+2,43$ \\
\hline $2015-2016$ & $-29,75$ & $+16,72$ & $-3,76$ & $-3,76$ \\
\hline $2016-2017$ & $+3,09$ & $+2,89$ & $+8,05$ & $+8,05$ \\
\hline $2017-2018$ & $+201,83$ & $-66,10$ & $-0,55$ & $-0,55$ \\
\hline $2018-2019$ & $-8,20$ & $+83,45$ & $-0,27$ & $-0,27$ \\
\hline
\end{tabular}

(-) Abrasion and (+) Accretion

Changes in the shoreline at point A have a maximum accretion in 2012-2013 along $278.67 \mathrm{~m}$, at point B there is a maximum abrasion of $-154.78 \mathrm{~m}$ in 2010-2011, in 2012-2013 at point $\mathrm{C}$ there is a maximum abrasion of $-76.85 \mathrm{~m}$, and at point $\mathrm{D}$ the maximum accretion is $-8.05 \mathrm{~m}$ which occurred in 2016-2017.

Interpretation data between Google Earth satellite imagery and superimpose by converting via AutoCAD results from the data obtained from the segmentation in every $10 \mathrm{~km}$ which tends to be more tenuous and too large. The second modeling with three $\mathrm{km}$ from the starting point of the coordinates and the end point of the coordinates obtained from the mapping results of Google Earth 2009 to 2019. The segmentation in every $3 \mathrm{~km}$ is denser and more precise than the accuracy of the data, making it easier for further analysis to determine which parts are included in the abrasion and accretion. Table 2 shows the changes of the coastline in every $3 \mathrm{~km}$ for the year 2009 to the year 2019.

Table 2:-Changes in the coastline in every $3 \mathrm{~km}$ for the year 2009 to the year 2019.

\begin{tabular}{|c|c|c|c|c|c|c|c|c|c|c|}
\hline \multirow[b]{2}{*}{$\begin{array}{l}\text { Point } \\
\text { (m) }\end{array}$} & \multicolumn{10}{|c|}{ Year } \\
\hline & $\begin{array}{c}2009- \\
2010\end{array}$ & $\begin{array}{l}2010- \\
2011\end{array}$ & $\begin{array}{c}2011- \\
2012\end{array}$ & $\begin{array}{l}2012- \\
2013\end{array}$ & $\begin{array}{l}2013- \\
2014\end{array}$ & $\begin{array}{l}2014- \\
2015\end{array}$ & $\begin{array}{l}2015- \\
2016\end{array}$ & $\begin{array}{l}2016- \\
2017\end{array}$ & $\begin{array}{l}2017- \\
2018\end{array}$ & $\begin{array}{c}2018- \\
2019\end{array}$ \\
\hline A & -3.66 & 0.56 & -1.60 & +278.67 & +32.32 & +153.70 & -29.75 & +3.09 & +201.83 & -8.20 \\
\hline A1 & -1.11 & +2.86 & -5.29 & +838.10 & +57.64 & +76.86 & -7.43 & +212.04 & +252.71 & -4.83 \\
\hline A2 & -0.90 & -8.16 & +0.22 & +0.22 & +7.33 & +47.64 & -37.85 & -357.96 & -18.64 & -7.61 \\
\hline A3 & $-0,57$ & -31.44 & -20.67 & +8.69 & +12.72 & +2.79 & +1.27 & -3.96 & -21.98 & +1.86 \\
\hline $\mathrm{B}$ & +39.83 & -154.78 & -2.85 & +11.14 & 0 & -111.47 & -16.72 & +2.89 & -66.10 & +83.45 \\
\hline B1 & -0.72 & -0.28 & +6.25 & -91.45 & 0 & -13.07 & -2.62 & -17.25 & -37.58 & -0.67 \\
\hline B2 & -0.35 & -1.37 & +3.77 & +1.55 & 0 & +62.89 & -67.49 & -23.23 & +34.98 & -39.39 \\
\hline B3 & +3.32 & +8.96 & +23.19 & -38.26 & 0 & -1.92 & +10.89 & -12.21 & -0.18 & -4.29 \\
\hline $\mathrm{C}$ & +1.24 & +1.12 & +1.69 & +4.49 & -2.02 & +2.43 & -3.76 & +8.05 & -0.55 & -0.27 \\
\hline $\mathrm{C} 1$ & +0.21 & -90.61 & +3.34 & -50.39 & 0 & -12.40 & -7.31 & +4.62 & -13.21 & +0.90 \\
\hline $\mathrm{C} 2$ & -2.95 & +0.16 & -12.18 & -0.77 & 0 & +5.64 & -5.69 & +0.18 & +29.80 & +21.37 \\
\hline $\mathrm{C} 3$ & -12.59 & +896.36 & -10.21 & +164.61 & 0 & +267.19 & $\begin{array}{l}+597.21 \\
\end{array}$ & -624.98 & -22.69 & +67.89 \\
\hline $\mathrm{D}$ & +1.79 & +1.12 & +1.69 & +4.49 & -2.02 & +2.43 & -3.76 & +8.05 & -0.55 & -0.27 \\
\hline
\end{tabular}

(-) Abrasion and (+) Accretion

Changes in the shoreline occur at the maximum accretion point:A1 of $+838.10 \mathrm{~m}$ in the years $2012-2013$, B2 of $+62.89 \mathrm{~m}$ in $2014-2015, \mathrm{C} 2$ of $+29.80 \mathrm{~m}$, in the years $2012-2013$, $\mathrm{C} 3$ of $+896.36 \mathrm{~m}$ in the years $2010-2011$. There is maximum abrasion at the point:A2 of $-357.96 \mathrm{~m}$ in 2016-2017, A3 of $-31.44 \mathrm{~m}$ in the years 2010-2011, B1 of -91.45 $\mathrm{m}$ in the years 2012-2013, B3 of $-38.26 \mathrm{~m}$ in the years 2012-2013, and C1 of $-90.6 \mathrm{~m}$ in 2010-2011.

After obtaining the results of modeling changes in the coastline of each point in each year, the next analysis uses a zone or route analysis system. Shoreline change modeling with this route system, coastline data from 2009 to 2019 from Google Earth is plotted manually per box with a length times width adjusted to the overall scale. Shoreline change modeling with this route system is made with a box model consisting of 84 boxes. This shoreline change analysis is focused on the change in maximum distance and maximum area that occurs. The maximum distance and 
maximum area of change in the shoreline also indicates the occurrence of abrasion and/or accretion. The shoreline change modeling with this route system focuses on routes between points A1-A2; routes between points B2-B3 and; as well as routes between points $\mathrm{C} 3$ and $\mathrm{C} 4$. Table 3 shows the distance and are to change of coastline with route system.

Table 3:- Distance and Area to Change of Coastline with Route System.

\begin{tabular}{|l|r|r|r|}
\hline \multicolumn{1}{|c|}{ Year } & Distance $(\mathrm{m})$ & \multicolumn{1}{c|}{ Area $\left(\mathrm{m}^{2}\right)$} \\
\hline A1-A2 & $2011-2019$ & -1434 & $-1,419,5332$ \\
\hline B2-B3 & $2010-2019$ & +1284 & $+1,114,501$ \\
\hline C3-C4 & $2009-2019$ & -1982 & $-1,052,3231$ \\
\hline
\end{tabular}

(-) Abrasion and (+) Accretion

\section{Conclusions:-}

Analysis of shoreline changes in Subang Regency, West Java using the satellite mapping method. The analysis of shoreline changes is focused on changes in distance and area according to satellite mapping data from 2009 to 2019. The results of changes in distance and area of changes in coastline determine the occurrence of abrasion and/or accretion. Modeling using routes is easier to see results that are more specific and easier to use. The superimpose result of changes in the coastline of the route between points A1-A2 experienced abrasion along -1434 $\mathrm{m}$ with an area of 1,419,532 $\mathrm{m}^{2}$; route between points B2-B3 experiences accretion along $+1284 \mathrm{~m}$ with an area of 1,114,501 $\mathrm{m}^{2}$; as well as the route between points C3-C4 experiencing accretion along $+1982 \mathrm{~m}$ with an area of 1,052,321 $\mathrm{m}^{2}$. Changes in the coastline of Subang Regency, West Java, experience abrasion and accretion which can reduce coastal functions and affect coastal buildings and need special attention in maintaining the sustainability of the ecosystem around the coast in Subang Regency, West Java, Indonesia.

\section{References:-}

1. Meilianda, E., Pradhan, B., Syamsidik, Comfort, L.K., Alfian, D. Juanda, R., Syahreza, S., Munadi, K. Assessment of post-tsunami disaster land use/land cover change and potential impact of future sea-level rise to low-lying coastal areas: A case study of Banda Aceh coast of Indonesia. International Journal of Disaster Risk Reduction. December 2019; 41.

2. Kakisina, T.J., Anggoro, S., Hartoko, A., Suripin. Analysis of the Impact of Land Use on the Degradation of Coastal Areas at Ambon Bay-Mollucas Province Indonesia. Procedia Environmental Sciences. 2015; 23: 26673.

3. Dada, O.A., Agbaje, A.O., Adesina, R.B., Asiwaju-Bello, A. Effect of coastal land use change on coastline dynamics along the Nigerian Transgressive Mahin mud coast. Ocean \& Coastal Management. 1 Februari 2019; 168: 251-64.

4. Chen, C., Fu, J., Zhang, S., Zhao, X. Coastline information extraction based on the tasseled cap transformation of Landsat-8 OLI images. Estuarine, Coastal and Shelf Science. 5 February 2019; 217: 281-91.

5. Ai, B., Zhang, R., Zhang, H., Ma, C., Gu, F. Dynamic process and artificial mechanism of coastline change in the Pearl River Estuary.Regional Studies in Marine Science. July 2019; 30: 100715.

6. Dewi, R.S., Bijker, W. Dynamics of shoreline changes in the coastal region of Sayung, Indonesia. The Egyptian Journal of Remote Sensing and Space Science. August 2020; 23(2):181-93.

7. Thior, M., Sané, T., Dièye, E.B., Sy, O., Cissokho, D., Ba, B.D., Descroix, L.Coastline dynamics of the northern Lower Casamance (Senegal) and southern Gambia littoral from 1968 to 2017. Journal of African Earth Sciences. December 2019; 160: 103611.

8. Husnayaen, Rimba, A.B., Osawa, T., Parwata, I.Y.S, As-syakur, A.R., Kasim, F., Astarini, I.A. Physical assessment of coastal vulnerability under enhanced land subsidence in Semarang, Indonesia, using multi-sensor satellite data. Advances in Space Research. April 2018; 61(8); 207-19.

9. Kalther, J. and Itaya, A. Coastline changes and their effects on land use and cover in Subang, Indonesia. Journal of Coastal Conservation. 2020; 24: Article number: 16.

10. Wang, X., Xiao, X., Zou, Z., Chen, B., Ma, J., Dong, J., Doughty, R.B., Zhong, Q., Qin, Y., Dai, S., Li, X., Zhao, B., Li, B. Tracking annual changes of coastal tidal flats in China during 1986-2016 through analyses of Landsat images with Google Earth Engine. Remote Sensing of Environment. March 2020; 238: 110987.

11. Wang, X., Xiao, X., Zhou, Z., Hou, L., Qin, Y., Dong, J., Doughty, R.B., Chen, B., Zhang, X., Chen, Y., Ma, J., Zhao, B., Li, Bo. Mapping coastal wetlands of China using time series Landsat images in 2018 and Google Earth Engine. ISPRS Journal of Photogrammetry and Remote Sensing. May 2020; 163:312-26. 
12. Yasmin, N. 2019. Introduction to AutoCAD 2019 for Civil Engineering Application. SDC Publication, KS.

13. Chang, Y., Chu, K., Chuang, L.Z.H.C. Sustainable coastal zone planning based on historical coastline changes: A model from case study in Tainan, Taiwan. Landscape and Urban Planning. June 2018; 174:24-32.

14. Dai, C., Howat, I.M., Larour, E., Husby, E. Coastline extraction from repeat high resolution satellite imagery. Remote Sensing of Environment. August 2019; 229: 260-70.

15. Foster-Martinez, M.R., Alizad, K., Hagen, S.C. Estimating wave attenuation at the coastal land margin with a GIS toolbox. Environmental Modelling \& Software. October 2020. 132:104788.

16. Khairuddin, B., Yulianda, F., Kusmana, C., Yonvitner. Degradation Mangrove by Using Landsat 5 TM and Landsat 8 OLI Image in Mempawah Regency, West Kalimantan Province year 1989 - 2014. Procedia Earth and Planetary Science. 2016. 33: 460-4.

17. Narra, P., Coelho, C., Sancho, F. Multicriteria GIS-based estimation of coastal erosion risk: Implementation to Aveiro sandy coast, Portugal. Ocean \& Coastal Management. 1 August 2019; 178: 104845.

18. Prasita, V.D. Determination of Shoreline Changes from 2002 to 2014 in the Mangrove Conservation Areas of Pamurbaya Using GIS. Procedia Earth and Planetary Science. 2015. 14: 25-32. 